\title{
Ukraine as a Geopolitical Priority of the Russian Federation
}

\section{Ukraina jako geopolityczny priorytet Federacji Rosyjskiej}

\section{- Abstrakt •}

Artykuł definiuje znaczenie konfrontacji pomiędzy wiodącymi ośrodkami presji politycznej. Zgodnie z sytuacją geopolityczną, Ukraina może stać się głównym przedmiotem konfrontacji pomiędzy Stanami Zjednoczonymi, Rosją i Unią Europejską w celu podniesienia ich znaczenia w rejonie euroazjatyckim. Obecnie Ukraina jest uznawana za jeden z krajów kluczowych dla transformacji istniejącego porządku globalnego.

Słowa kluczowe: Ukraina, Rosja, USA, UE, porządek globalny, światowe ośrodki geopolityczne, konfrontacja mocarstw

\section{- Abstract •}

The article determines the meaning of confrontation between the leading centers of international pressure. According to the geographical status, Ukraine can be the main confrontation object between the USA, Russia, and the EU in order to show their presence in the Eurasian region. Nowadays Ukraine is considered to be one of the key countries that can transform the world order.

Keywords: Ukraine, Russia, the USA, EU, world order, world geopolitical centers, confrontation of great powers

The issue of transforming the existing world order is updated on the rise as geopolitical contradictions between the major subjects of international influence in existing and new intersections of their interests. The historical retrospective shows that the major powers expanded their influence mainly through expansion towards small and medium-sized countries. Clashes of interests of great powers led to large-scale conflicts, two of which were on a global scale. After the end of World War II economic expansion came to replace the military force. In modern terms, the information revolution has brought a number of new categories of geopolitical analysis, the central of which are the "information war", "hybrid warfare", "semantic war", "information weapons", etc. One of the challenges of modern 
information war is to create an enabling environment for any operations that have a geopolitical and geoeconomic character.

Analyzing the current situation in the Eurasian region, we can talk about acceleration of civilizational confrontation. This is why the geopolitical status of Ukraine as part of the geopolitical front in a inter-civilizational conflict is a catalyst for Eurasian and world order change in general. The modern conflict in Ukraine goes far beyond local war between Kyiv and terrorist groups supported by Russia that occupied part of Donbas and created in that area LPR/DPR - fictitious public formations. The deployment of armed struggle in Ukraine was caused primarily by a clash of geopolitical interests of three global centers of world/civilizational influence - Russia, the EU, and the US in this part of Eastern Europe. In the growing geopolitical struggle, the West pursues the goal to consolidate its interests through strengthening liberal-democratic values in Eastern Europe, using such young democracies like Ukraine, Georgia, and Moldova. All this should ultimately make Russian influence in the Eurasian region weaker. Thus, Ukraine has got the role of a large outpost of American pressure on Moscow. Russia, in turn, wants to preserve its influence on the post-Soviet countries and to prevent the pro-Western economic and political changes. The latter applies especially to Ukraine as to one of the most important post-Soviet countries (Фесенко, 2014, p. 10-11).

The questions of subjectivization of Ukraine in the new geopolitical realities became the subject of interest of many experts, analysts and political scientists, scholars both in our country and abroad. Scientific research and analytical articles apply to events that are taking place in Ukraine and the international situation that arose in relation with the growing confrontation between Russia and the West for spheres of geopolitical influence in Eurasia. All the studies and the authors that are working on geopolitical problems of Eurasian and Ukrainian context we can categorize in three separate groups. The first one is represented by Russian political scientists, historians, sociologists and ideologues of Eurasianism such as: K. Hadzhyiev, V. Dergachov, A. Dugin, S. Luzianin, S. Panarin, K. Sorokin, T. Shakleyina, L. Shevtsova, etc. Another group of scientists are representatives of the domestic political science thought, namely: A. Voloshyn, N. Doroshko, R. Zhangozha, A. Irkhin, L. Kovryk-Tokar, G. Perepelytsia, A. Potekhin, M. Fesenko, M. Hackard, L. Chekalenko, A. Shergin, and others. Finally, the third group consists of representatives of Western scholars of political science schools to which we assign A. Aslund, Z. Brzezinski, T. Graham, E. Kuchins, G. Mirshaymer, A. Stent, A. Umland, J. Sherr, and more.

Professor Ekaterina Turkina from the University of Pittsburgh believes that these developments and, in general, the Russia-Ukraine relationship represent a fascinating case for analysis. It is not evident why the two countries that are so 
close on many levels - from a common history, family and friendship ties, strong business ties, and interconnections between political elites - failed to secure partnership and engaged in an escalating confrontation. Ukraine is highly important. Europeanists emphasize Kyiv and Ukraine as key to Russian Europeanness, because Kievan Rus, a prosperous and vast Russian state was an inalienable part of the medieval European landscape. Eurasianism believe that Russia is a civilization on its own (with Moscow being the "Third Rome" and with Russians as a titular ethnos). In geopolitics, this cultural identity translates into the Russian geopolitical space: the Russian orbit includes smaller systems, which altogether present an alliance of nations. So, this vision focuses on Russia as a regional power rather than a nation-state. In this vision Ukraine is important as it is perceived as belonging to the Russian orbit and civilization. Nationalism is related to promoting the cultural unity of Russians and is closely related to pan-Slavism. Here, Slavic ethnic ties with Ukrainians are significant. Like in the European vision, both in Eurasionist and nationalist visions, the symbolism of Kievan Rus is of equal importance, as it represents the roots of Russian Orthodoxy and is largely perceived as being at the heart of the formation of Russian civilization; modern Ukraine is a continuation of the so-called "Russian World" (Turkina, 2015, p. 192).

The Russian elite emphasizes that Ukraine is part of the Orthodox (Russian) civilization, which accidentally turned into a separate territory as a result of "the greatest geopolitical catastrophe of the twentieth century" - collapse of the USSR. Therefore, having weaker resources nowadays, Russia considers Ukraine as "failed states" that has to be reunited in a common Slavic community. The propaganda of politics during deployment of the so-called hybrid war was aimed to prove that Ukraine can maintain its territorial integrity and viability only under conditions of constitutional reform which should be the result of federalization of the country. According to the plan of Russian Federation, federalization of Ukraine should give special status to the south-eastern regions where a significant percentage of Russian and Russian-speaking population is present. These territories, according to Moscow, would be a convenient lever of pressure on Kyiv in case of unfair policy towards Russia. Another factor that motivates Russia to use force in Ukraine is a categorical rejection of the West and Euro-Atlantic aspirations of Kyiv in which the Kremlin sees a potential threat to its security. A way out of this situation could be the "Finlandization" of Ukraine, which excludes its accession to NATO, but this mechanism does not satisfy either Ukraine or major geopolitical players (Racz, 2014, p. 88-104).

In general, the aim of this publication is the representation and analysis of the Ukrainian factor in the formation of a new world order, as well as coverage 
of the specific of geopolitical struggle for the influence in Eurasia between Russia and the West.

It is noteworthy that the paradigm of inter-civilizational confrontation was grounded by well-known American political scientist Samuel Huntington. He predicted the opposition in Ukraine, which is geographically located between the Orthodox and Eastern (Orthodox) and Western (Catholic) civilizations. In his opinion, these very states are the most malleable to the conflict confrontation of powerful international actors. We must note that this paradigm implies the existence of a number of civilizations whose boundaries do not always coincide with the boundaries of states or their coalitions. Therefore, Samuel Huntington predicted more intrastate conflict in Ukraine than direct clash with the Russian state. The analyst did not exclude a high probability of collapse of Ukraine according to Czechoslovak or Yugoslav scenario (Хантингтон, 2011, p. 39). However, as we see, even to such eminent experts it is difficult to predict the actual behavior of Russia in the most prominent geopolitical struggle in the modern world. It turned out that the causes of social and cultural confrontation in the Ukrainian state was primarily an external factor (Кондратенко, 2014, p. 155-156).

In the conditions of the Eastern threat liquidation in Europe and the start of the implementation of a fully-fledged EU foreign policy, there was still a question of appropriateness; for the United States it was also the question of the price of total further reliance of Europe in the field of security and defense. The United States began to shift the priorities and political-military resources to resolve and prevent the security challenges in the regions of Central and Southeast Asia and the Middle East. As a result, American military presence in Europe decreased from 300 to 80 thousand people. That means that the United States, which accounts for around three-quarters of all NATO defence spending, will want European allies to do more to defend themselves (Sytas, Croft, 2014).

Central and West European countries cut defence spending by 6.5 percent between 2004 and 2013 while Russian military spending doubled over that period, the Stockholm International Peace Research Institute, a defence think-tank, said last month. While Latvia and Lithuania have just pledged to more than double their military spending, other allies, such as Slovakia, say they cannot afford any increase. But despite budget cuts, NATO remains far more capable than Russia. Although Russia's military spending has risen, its armed forces have shrunk under reforms aimed at turning them into a better equipped, more professional military. Rather than keeping large numbers of forces in Eastern Europe, NATO could rotate forces from other NATO allies in the region while preparing to reinforce quickly if needed (Sytas, Croft, 2014). 
Due to a number of international circumstances, Ukraine found itself at the epicenter of geopolitical turbulence. We can say confidently that our country is in the center of a clash of great interest, geopolitical gravitation, and civilizational break. Today we see increased competition for influence in Eurasia through the collision of two paradigms of integration - European (market, democratic, civil) and Eurasian (authoritarian, corrupt, and administrative power). Russia appears as an undisputed leader of Eurasian integration structures, including the Eurasian Economic Community and EES. This organization is a materialized version of Dugin ideology, actively promoted by their apologists. Eurasian Community and now also the Eurasian Economic Union are the means of strengthening regional leadership and imperial renaissance. The main task of the Russian leadership is to secure Ukraine's membership in such organizations that are actively multiplying in the former USSR. By the way, the idea of joining the Eurasian integration structures was popular among a large part of the Ukrainian elite for a long time. The latter can be largely explained by the fact that EEC was a typical post-Soviet Union dictatorship that was remarkable for its reluctance to allow progressive changes and that sought to preserve a commodity-based economic system of corruption schemes. Ukrainian oligarchs for the conservation and enhancement of their capital were shying from transparent commercial arrangements that are particularly needed for economic and political reforms in the context of the Copenhagen criteria (Сушко, Аісничук, 2002). In recent years, some experts produced messages about Ukraine's surrender of the Euro project and the final choice in favor of Russian Eurasianism. Such political pessimism was reinforced in 2013 by the refusal of the then President Viktor Yanukovych to sign the Ukraine-European Union Association Agreement because of the promises of credit support from Russia. After withdrawal of V. Yanukovych as president of Ukraine, Russia lost its primary means of keeping Ukraine in the wake of its geopolitical influence. As a result of the events in Ukraine and establishment of pro-Western political elite, Russia began to implement the annexation scenario of the Crimea and started to support separatists in Donbas, which led to a large-scale conflict (Coffey, Kochis, 2014).

Ukraine has become a victim of political confrontation between the three world superpowers - Russia, the EU, and the US. For instance, the Ukrainian journalist Lilia Shevtsova writes that "Ukraine is a victim of both the Russian system's struggle for survival and the West's inability to protect the international legal space" (Shevtsova, 2015).

In general, now opens a new page of Russian foreign policy, its international relations, and security strategy formation. Russia had to respond to the transformation of the political regime in Ukraine and took it as a challenge to its status 
and a geopolitical threat from the United States (Trenin, 2014). As a result, an increase in the Russian military presence in Ukraine followed. According to most of Western as well as local experts, Russia, using uncertainty of the West, seeks to "freeze" the conflict or at least to end it on favorable terms, which lie in the preservation of Russian cultural identity in the southeast, the official confirmation of the status of Russian as a second language state, and guarantees that Kyiv confirms the position of not joining NATO and the EU in the future (Migranyan, 2014).

The events of the Russian-Ukrainian conflict were the subject of the great geopolitical game in the EU and NATO for the influence over the Eastern policy, including the informal competition between Great Britain and Germany. At the end of July 2014, the British magazine Independent, on the basis of the information from its own sources, revealed the existence of a secret plan-agreement between Angela Merkel and Vladimir Putin to resolve the conflict in Ukraine, which included the recognition of the annexation of Crimea and refusal of Ukrainian entry to NATO. This plan was allegedly never realized because of the accident of the Malaysian airliner over the Donetsk Region (Pagano, 2014).

There is a theory that Russia was interested in Ukrainian escalation of events in an attempt to redistribute the spheres of influence with Germany. Russia was counting on economic control over the southern and eastern regions of Ukraine and Germany through formal Kyiv convergence with the EU would have access to the center and west, thus strengthening its position in Eastern Europe and the EU as a whole. However, the United States as the world hegemonic leader are not interested in the redistribution of global balance of power and opposed the creation of continental bloc of Germany. The result was that Washington actually persuaded Germany to share its viewpoint and promised to help to increase energy independence of the EU through the diversification of energy supplies (Романенко, 2015).

Despite the fact that Ukraine claims to be a geopolitical bridge between Europe and Eurasia, it fulfills the role of a border between the EU and Russia. Speaking of geostrategy of Russia, we should state that Ukraine is the last bastion on the way of Western democracies for the Kremlin and Russia itself. Because of Ukraine, but rather by supporting the conflict in eastern Ukraine, Russia is trying to push out the EU and the US in order to maintain spheres of influence in Eurasia. However, it is known that Ukraine for Putin is just one battle in the confrontation with the US, along with such objects of geopolitics as Syria or Iran with its nuclear program. Therefore, the victory of Russia in Ukraine will be regarded as another defeat of the United States (Бондаренко, 2014). In the struggle for Ukraine Putin shows significant "interest" in the Ukrainian defense industry and that is 
partly due to his desire to establish control over the south-eastern regions where high-tech military is primarily concentrated, in particular Pivdenmash (Dnepropetrovsk), Hartron (Kharkiv) Motor-Sich (Zaporizhzhia), Mykolayivskyi Shipyard plant, and others. Secondly, Russia is interested in infrastructural facilities in the south of Ukraine. Access to Transdniestria with subordinate Crimea would allow Russia become stronger in the Black Sea basin, eventually to bring Turkey back from the American sphere of influence, and create the conditions for resolving the issue of alternative sources and supply routes to Europe by strengthening the position in Caspian region in the future. Against this backdrop, the US is trying to take revenge by involving Ukraine as a key Black Sea state into the orbit of influence after a series of defeats during the previous years, such as the failure of US policy in Syria and Iran (Бондаренко, 2014).

Overall, for the Kremlin, unlike the United States, Ukraine is part of a larger geopolitical project, a first step towards the Eurasian Union. We remind that the brass ideological foundation of the plan was the famous "Russian World" that without Ukraine and Kyiv as "mother of Slavic towns" minimizes the legitimization of "the Kremlin throne". The change of the independent Ukrainian state borders by annexation of the Crimean Peninsula from further fueling the conflict in the south-eastern regions has been a challenge in which Russia shaken the Western world and the existing world order in general. Well-known American historian T. Snyder believes that this behavior presents a challenge to the world order and the European security and sees the intentions to destroy the Ukrainian statehood (Габриэмян, 2014). In fact, after the Second World War in European history there were no cases of violent rejection of the sovereign states territories. A precedent to correction of the geopolitical paradigm of RF appeared in the context of protecting citizens abroad, whose number is about 25 million people, who create the foundation of the "Russian World". A number of analysts see the resolution of the Fourth World War (assuming that the Third World War was the Cold War) and the behavior of the Kremlin leader are often compared to the actions of Hitler in late 1930s. You can accept such an estimation of international situation, because world conflict actually started before the Crimean events, and the incorporation of Ukrainian territory only reaffirmed the intention of Russia "to move" west borders by force.

According to experts, Russia's victories in local conflicts are necessary for the preservation of the existing authoritarian regime. The example of this is the sharp jump in ranking of Russian president to over $80 \%$ after the Crimea. For example, it is traced that the rating of Russian leaders is growing in the time of aggravation of internal or external enemy or in case of threats to national security. Thus, dur- 
ing the military antiterrorist operation in the North Caucasus of Russia in 1999 (better known as the second Chechen war - O. K.) rating of the then President Boris Yeltsin grew within four months from $31 \%$ to $80 \%$. Another such example was the special operation of Russia in Georgia in 2008 after which the level of support for Putin rose to an unprecedented 88\% (Рейтинг Путина, 2015). Thus, according to the deterioration of the internal situation in Russia, authorities are able to distract people for some time from the social problems through exploitation the nostalgic thesis of Russia special features as the core of the Orthodox Church, located in a hostile environment, opposing the depraved West. In addition, all local conflicts in Russia with the media and propaganda are trying to show the US policy as aimed to isolate and destroy Russian sovereignty. Thus, one of the main components of internal geopolitics is to create an enemy to consolidate the society around the regime and the leader. However, support for escalation in Ukraine should be viewed as an attempt of Russian elite to keep Putin's authoritarian system in the conditions of recession and imposed sanctions. The successful Europeanization and prosperity of Ukraine would put into question the effectiveness of anti-democratic regimes in many post-Soviet countries, as well as in Russia. The fiasco of the strategy of successful transformation in Ukraine would serve as a clear example of democratic uprising of a large Orthodox country for the Russian society. Therefore, limited military intervention of Russia in Ukraine is aimed at the prevention of Kyiv reforms. Also, we can suppose that the strategy of Russia includes exhaustion and collapse of Ukraine not by the open large-scale military intervention and subversion of state provocation, but by discontent of population and removal of the pro-Western authorities (УмканА, 20Responding to developments in Ukraine and related actions by Russia has been a generally strong area of US - European coordination, though not completely without tension. The US and European analyses of developments have been largely aligned, and the two sides have openly sought to maximize their influence with parallel messages and mutually reinforcing actions, including extensive sanctions. Unlike the United States, which has relatively limited economic ties with Russia, many European countries have large and interdependent relationships with Russia in terms of trade, investment, finance, and energy. EU debates over sanctions contend with the economic value and political influence attached to these relationships; varying attitudes and outlooks on Russia based on history, geography, and culture; and doubts about the likely effectiveness of sanctions. US policy makers often express frustration at this process (Mix, 2015).

The political analysts say that since 2014, when Russia started its foreign invasion, US and European relations with Russia have become more adversarial 
in the context of Russia's annexation of Crimea and its actions in destabilizing Ukraine. So the bilateral relations between the two counterparts recently have only increased their priority. In National Security Strategy of 2015, Barack Obama has mentioned that during his years at the White House, the US have "renewed their alliances from Europe to Asia" in the background of the Russian aggression. "Russia's aggression in Ukraine makes clear that European security and the international rules and norms against territorial aggression cannot be taken for granted", wrote President Barack Obama in NSS-2015 (The National Security, 2015, p. 7-35).

To understand EU "soft power", it is necessary first to cast a glance at its hard power. As already noted, the military dimension remains the least developed aspect of EU foreign policy and is primarily geared towards humanitarian intervention and not towards power projection in the classic, coercive sense. The economic means have been more prevalent, in the form of trade agreements and development assistance, both typically accompanied by conditionality clauses. By these means, the EU has sought to pursue normative milieu goals. In this, the EU has often relied on its stronger economic position vis-à-vis partners or indeed on the regional hegemony it enjoys over most of the European continent. The financial inducements and positive conditionality that Ferrero-Waldner regarded as the EU's soft power are fully in keeping with the notions of civilian power, in that negotiation, contractual relationships, and economic incentives are central elements. But conditionality, whether positive or negative, and the sanctions implied, are, on a more rigorous understanding of power, clearly at the lower end of what can be termed hard power. At the same time, the EU's extensive trade ties with many parts of the world and its relatively generous development policies provide it with some important building blocks for developing soft power (Nielsen, 2013).

The weakness of the West, especially the EU, in relations with Russia are clearly manifested during the events of its military aggression on the territory of Ukraine. The annexation of Crimea in March 2014 brought an international condemnation but had no significant consequences for the aggressor. First of all, Europe and the US have shown unreadiness to conflict development in Eastern Europe when they started the formation of a real strategy to fight during the deployment of Russian full-scale unofficial intervention in the Ukrainian Donbass. After lengthy hopes of diplomatic policy of appeasement the aggressor, the EU Council has finally taken the decision to impose systemic sanctions (aka "third wave" sanctions), but only after the tragedy of the passenger jet MH17 in the Donetsk region in July, and then the entrance of the regular units of the Armed Forces of the Russian Federation into the territory of the region on the Independence Day of Ukraine on 24 August 
2014. In terms of defense, the Union can not offer anything to Ukraine but the traditional methods of "soft power", such as non-effective diplomatic support, the Association Agreement, the prospect of economic aid, and anti-Russian sanctions that will have long-term consequences. The irony of "soft power" is that it so often requires "hard power" policies to become effective (Grybinco, 2015, p. 76-77).

Russia is more and more concerned with FTA. In Moscow, there were a lot of talks about the risks that Ukraine will be a kind of European goods transit zone, thereby will fill the market by foreign products and will influence Russian producers. After all, it is because of pressure the Association Agreement between Ukraine and the EU was postponed to December 2015. However, such claims are issued at least due to the fact that a big part of the Russian market is formed by the products from Europe and their increase will not dramatically affect its structure.

Not quite proper is Russia's position to Ukraine's accession to NATO. More often we can hear rants of Kremlin leadership about the effect of the membership of Ukraine in NATO. Some leaders consider that it will radically disrupt the balance of power in the area of special interests. Ironically, however, even in Western political science discourse pro-Russian stance can be traced to some experts on Ukraine's rapprochement with NATO. A famous American scientist, Professor G. Mirshaymer of the University of Chicago expresses the special position on the policy of Realpolitik style and proves that it was the US who provoked Ukrainian internal conflict and the Russian-Ukrainian opposition as a whole. The political analyst maintains that the annexation of the Crimea was a response to the expansion of NATO, which is guided with realistic motives. Another reason for aggression was the version of the revolution in Ukraine, allegedly carried out with the support of the United States, which was the basis of Russian troops to enter Crimea and east being afraid of "right-wing" pro-American leadership (McFaul, Sestanovich, Mearsheimer, 2014). In short, the representative of the realistic trend proves that Russia in resorting to aggression acted against the unacceptable implementation scenario of further color revolutions and creation of new Western democracies by post-Soviet countries and inevitably their involvement in NATO. However, as we know, Ukraine is not even a potential candidate for NATO membership. In addition, there is a question why Putin's aggression was conducted almost fifteen years late, as NATO's eastward expansion started in 1999. Also as a result of the "expansion" of the Alliance in 2004 post-Soviet Baltic countries gained membership and Russia did not use force at that time. Another counterargument might be the last NATO enlargement in 2009, which involved Albania and Croatia. The latter in no way can be regarded as the so-called area of special interest to Moscow (Gidadhubli, 2004, p. 1886). 
Taking into consideration this state of affairs, we can reach a preliminary conclusion that the Kremlin is showing abnormal "offence" for the defeat in the Cold War and it finally proclaimed post-Soviet/Eurasian space as the area of their special interests, going even to the annexation of the territories of neighboring states. The counterstrategy of the West is the support of democratic values, territorial integrity, and sovereignty of Eurasia and their violation is the basis for the introduction of economic sanctions against Russia.

It is known that the introduction of sanction restrictions by the world's leading economic powers and the fall in world oil prices to 30 dollars per barrel become the deterrent factor that stopped the implementation of the project "Novorosia", which involved the creation of the territory of eight Ukrainian regions as puppet buffer states.

The vast majority of policy experts argue that solving networked or the socalled hybrid war and using the ambiguous position of some EU members such as the Czech Republic, Hungary, Austria, and Italy, Russia is doing her best to achieve prevention of turning Ukraine into a full-fledged geopolitical foothold for further expansion of West "Pax Americana" in Eurasia. Highlighting the potential for radical imbalance of checks and balances in the modern world, in one of his statements Russian President Vladimir Putin predicted multiplication of regional conflicts indirect interests of the great powers as a result of failure to reckon with the geopolitical interests of each other. This Russian leader said that risk should primarily include unstable countries that are at the intersection of geopolitical interests of the main centers of international power. Thus, according to the Russian president's rhetoric, such message essentially announced the start of a new Cold War between Russia and the West (Разочарованный крахом системы противовесов Путин, 2014).

Thus, during the current geopolitical and security crisis in the world we can observe the formation of a new international order involving the participation of almost all the great powers of our time. In particular the US is trying to further the participation of its allies to expand "Pax Americana". China and Russia, and to a lesser extent India and Brazil, traditionally opposed such a unipolar world. These states advocate building a world concert - multipolarity, which is an alternative to American global construct. In such circumstances, medium and small states are almost out involving reformatting world order, and often do serve as means to counter and defend global interests of the great powers. Ukraine has become a field of struggle of Atlantic and Eurasian paradigm transformation of world 
order and international security. There is a reason to believe that the destruction of the mechanisms of checks and balances and formation of precedent for borders change will initiate conflicts in the modern international environment. With the aggravation between major centers of power (US, EU, Russia), Ukraine is a significant factor of changing world order, but still it becomes more a kind of "experimental" area of geopolitics. Russia, with the great economic losses is trying to keep its neighbors in its influence despite minimal chances to win in the competition with the West. In general, depending on which of the leading international players will keep Kyiv, that international player will ultimately determine not only the future of the Eurasian terrain but of the whole world order.

\section{References:}

Фесенко, М.В. (2014). Україна як фактор трансформації міжнародного порядку. Зовнішні справи, 10, 10-13.

Turkina, E. (2015). Russia-Ukraine Crisis: Value-Based and Generational Perspective. Studies in Ethnicity and Nationalism, Vol.15, 1, 185-192.

Racz, A. (2014). Russia's Hybrid War in Ukraine Breaking the Enemy's Ability to Resist. Helsinki: FIIA.

Хантингтон, С. (2011). Столкновение цивилизащий. Москва: Астрель.

Кондратенко, О. Ю. (2014). Український фактор становлення нового світового поряаку. Політологічні записки, 2, 155-164.

Sytas, A, Croft, A. (2014, May 18). Insight - Ukraine Crisis will be "Game Changer" for NATO. Retrieved from: http://www.reuters.com/article/2014/05/18/us-ukraine-crisis-nato-insight-idUSBREA4H 01V20140518.

Сушко, О., Аісничук, О. (2002, October 11). $\epsilon_{в}$ АзЕС: економічний сир у політичній мимоловиі вступ до $\epsilon_{в р}$ АзЕС означатиме політичну капітуляцію України як європейської держави, Азеркамо тижня.

Coffey, L., Kochis, D. (2014, November 26). Russia's Invasion of Ukraine: The U.S. Needs a Strate. Retrieved from: http://www.heritage.org/research/reports/2014/11/russiasinvasion-of-ukraine-the-us-needs-a-strategy.

Shevtsova, L. (2015, February 12). The Kremlin Is Winning. Retrieved from: http://www. the-american interest.com/2015/02/12/the-kremlin-is-winning/.

Trenin, D. (2014, July 29). Europe's Nightmare Coming True: America vs. Russia...Again. Retrieved from: http://nationalinterest.org/feature/europes-nightmare-coming-trueamerica-vs-russiaagain-10971.

Migranyan, A. (2014, July 30). What Is at Stake in Ukraine. Retrieved from: http://nationalinterest.org/feature/europes-nightmare-coming-true-america-vs-russiaagain-10971.

Pagano, M. (2014, July 31). Land for gas: Merkel and Putin Discussed Secret Deal Could end Ukraine Crisis. Retrieved from: http://www.independent.co.uk/news/world/europe/ land-forgas-secret-german-deal-could-end-ukraine-crisis-9638764.html. 
Романенко, Ю. (2015, January 20). О вызовах и новых возможностях для Украины наследующих этапах револющии. Retrieved from: http:/hvylya.net/analytics/geopolitics/ o-vyizovah-i-novyih-vozmozhnostyah-dlya-ukrainyi-na-sleduyushih-etapah-revolyutsii.html.

Бондаренко, К. (2014, April 29). Навіщо Путіну Україна. Retrieved from: http://tsn.ua/ analitika/navischo-putinu-ukrayina-347542.html.

Габриэлян, Е. (2014, March 31). Тимоти Снайдер: "Цель Путина - разрушить украинскую государственность", Источник. Retrieved from: http://ru.rfi.fr/ukraina/20140331timoti-snaider-tsel-putina-razrushit-ukrainskuyu-gosudarstvennost/.

Рейтинг Путина: аномалия или закономерность. (2015, January 15). Retrieved from: http://www.levada.ru/15-01-2015/reiting-putina-anomaliya-ili-zakonomernost.

Умкана, А. (2015, January 19). Роль и цели Кремля в “украинском” кризисе. Retrieved from: http://www.geopolitika.lt/index.php?artc=7120.

The National Security Strategy of the United States of America. (2015, February). Washington D. C.

Nielsen, K. (2013). EU Soft Power and the Capability-Expectations Gap. Journal of Contemporary European Research Vol.9, Iss.5, 723-739.

Grybinco, A. (2015). International Interest of Great Britain in the Conditions of the Modern Crisis of the European Security System. Historia i Polityka, 4 (21), 67-83.

McFaul, M., Sestanovich, S., Mearsheimer, J. (2014). Faulty Powers. Who Started the Ukraine Crisis? Retrieved from: http://www.foreignaffairs.com/articles/142260/michael-mcfaul-stephen-sestanovich-john-j-mearsheimer/faulty-powers.

Gidadhubli, R. (2004). Expansion of NATO: Russia's Dilemma. Economic and Political Weekly, Vol. 39,19, 1885-1887.

Разочарованный крахом системь противовесов Путин предрек планете "ряд острьх конфликтов”. (2014, October 24). Retrieved from: http://nvua.net/world/Putin-prigrozil-miru-ryadom-ostryh-konfliktov--17538.html.15). 